\title{
REVOLUCÕES NO ATLÂNTICO: BRASIL E PORTUGAL NA DÉCADA DE 20 DO OITOCENTOS
}

ADRIANA PEREIRA CAMPOS ${ }^{1}$

KÁTIA SAUSEN DA MOTTA ${ }^{2}$

UNIVERSIDADE FEDERAL DO ESPÍRITO SANTO

VITÓRIA - ESPÍRITO SANTO - BRASIL

No ano do bicentenário da Revolução de 1820, organizamos junto à Revista Ágora o dossiê "Revoluções no Atlântico: Brasil e Portugal na década de 20 do Oitocentos". O decênio de 1820 foi marcado por diversos movimentos revolucionários em Portugal e no Brasil. A Revolução do Porto inaugurou a agenda de sublevações no mundo português, configurando-se acontecimento que influenciaria nos rumos políticos nos dois lados do Atlântico.

Inspirada em princípios liberais, o movimento iniciado na cidade de Porto, em poucas semanas alcançaria Lisboa e não tardaria a ser notícia também no Brasil. Verdadeira guerra literária fora travada na imprensa no Brasil e em Portugal. Periódicos e folhetos difundiam nova pauta política, ressignificando conceitos e divulgando novo vocabulário constitucional.

Um dos efeitos imediatos do movimento liberal vintista foi a adesão de províncias da então América Portuguesa, que receberam com entusiasmo as novidades revolucionárias do ultramar, como a convocação das Cortes e a promulgação das Bases da Constituição Portuguesa. Enquanto a primeira abria um novo fórum de debates representativos, a publicação do documento materializaria os princípios ilustrados e constitucionalistas sob os quais os representantes do Império Português elaborariam a futura constituição.

O artigo Oposição à Revolução Constitucional Portuguesa em 1820 - um folheto censurado de F. J. da Madre de Deus, de autoria de Vital Moreira e José Domingues, contempla justamente o debate constitucional no contexto da Revolução Liberal portuguesa e o pensamento de resistência ao curso radical do movimento. A partir da análise do panfleto "Voz da Razão e da verdade dirigida aos Portugueses", escrito por

\footnotetext{
${ }^{1}$ Doutora em História (UFRJ). Professora do Departamento de História da Universidade Federal do Espírito Santo e dos Programas de Pós-Graduação em História e em Direito da mesma instituição. Coordenadora do Laboratório de História, Poder e Linguagens (UFES). Coordenadora de Projeto PRONEM Edital 06/2019 da Fundação de Amparo à Pesquisa e Inovação do Estado do Espírito Santo - FAPES. Bolsista produtividade do CNPq. Editora Chefe da Revista Ágora desde janeiro de 2020. E-mail: acampos.vix@gmail.com.

${ }^{2}$ Doutora em História (UFES). Pesquisadora do Laboratório de História, Poder e Linguagens (UFES). Atua no Programa de PósGraduação em História da Universidade Federal do Espírito Santo como bolsista do Programa de Fixação de Doutores da Capes/Fapes, desenvolvendo pesquisa de pós-doutorado. Pesquisadora do Projeto PRONEM Edital 06/2019 da Fundação de Amparo à Pesquisa e Inovação do Estado do Espírito Santo - FAPES. Vice Editora-chefe da Revista Ágora desde janeiro de 2020. E-mail: katiasmotta@gmail.com.
} 
Faustino José da Madre de Deus e censurado para publicação, os autores discutem certa proposta política vinculada a um constitucionalismo conservador que se distanciava dos princípios triunfantes em 1820 e consagrados na Constituição Portuguesa de 1822. Embora defendesse uma monarquia constitucional, Madre de Deus advogava pelo papel proeminente do rei no novo sistema político, incluindo na confecção das leis fundamentais do Estado, relegando às Cortes papel secundário ou meramente consultivo.

Sobre o mesmo contexto, insere-se o artigo de Alexandre Bellini Tasca, intitulado Integrar, conciliar, partir: as Cortes de Lisboa entre Portugueses de ambos os hemisférios. O autor analisa a dinâmica dos embates discursivos nas Cortes, focalizando as linguagens, ideias e projetos políticos em disputa na elaboração da Constituição da nação portuguesa e as tensões entre os deputados de ambos os lados do Atlântico. Na problemática pretensão dos constituintes em estabelecer o princípio de soberania nacional sobre território plural e descontínuo e com população diversa social e culturalmente, o autor evidencia como conceitos e acontecimentos do passado são mobilizados para legitimar ora posições de integração e conciliação entre Brasil e Portugal, ora de criação de uma nova nação, o Brasil.

Outra contribuição para o dossiê é o trabalho de Luis Otávio Vieira, intitulado Gerações da Independência: diversidades geracionais na imprensa do Brasil entre 1808 e 1831. Ao abordar a ampla gama de periódicos que influenciaram o debate público no processo de independência do Brasil, o autor analisa as gerações de editores e explora a relação entre o campo das experiências históricas e as ações e trajetórias políticas desses personagens. Para além de compreender a conjuntura a partir da atuação de uma única geração de produtores de periódicos, Vieira destaca o processo de independência como um campo de ação multigeracional que impactou a reelaboração semântica de conceitos, projetos políticos e, consequentemente, de expectativas de futuro. O manuseio do conceito de revolução se torna paradigmático para demonstrar como experiências revolucionárias do findar do século XVIII e primeiras décadas do XIX foram articuladas de formas distintas nos discursos das gerações de editores no Brasil.

Com foco também na imprensa, o artigo de Fernanda Pandolfi, com o título Narrativas Públicas e Constitucionalismo na Abdicação de D. Pedro I em 1831, discute o papel das 
narrativas disseminadas na esfera pública no processo de abdicação de Dom Pedro I. A partir dos rumores em torno da "recolonização" e da figura do Imperador como "antinacional", a autora evidencia como relatos que misturavam notícias falsas, suposições, fatos e amplo leque de teorias conspiratórias, influenciaram a realidade política da época e impactaram a perda de legitimidade do então primeiro imperador do Brasil. Fernanda Pandolfi aponta, também, certo legado da Revolução do Porto no modus operandi da imprensa, pautada ainda por uma pedagogia cívica que buscava atingir público amplo, e no retorno do tópico da recolonização originário da narrativa vintista.

Com efeito, os trabalhos reunidos no dossiê buscaram explorar a reverberação do movimento vintista em Portugal e nas diferentes regiões do Reino do Brasil no calor do desenrolar dos acontecimentos, como também as releituras da experiência revolucionária em solo já brasileiro. A imprensa, sem dúvida, desempenhou papel primordial na fomentação e ampliação dos debates e dos projetos políticos em disputa. Convidamos os leitores da Revista Ágora a percorrem as páginas da revista com o intuito de explorarem a temática que, embora já clássica, ainda se mantém fértil e inspiradora de novos estudos que conectam histórias dos dois lados do Atlântico. 